\title{
Testing the Relationship between Free Cash Flow and Company Performance in Borsa Istanbul
}

\author{
Eyup Kadioglu ${ }^{1}$, Saim Kilic ${ }^{2}$, Ender Aykut Yilmaz ${ }^{3}$ \\ ${ }^{1}$ Capital Markets Board, Ankara, Turkey \\ ${ }^{2}$ Istanbul Kemerburgaz University, Istanbul, Turkey \\ ${ }^{3}$ Iller Bankası A.S. Ankara, Turkey \\ Correspondence: Eyüp Kadığlu, Capital Markets Board, Ankara, Turkey. E-mail: eyup.kadioglu@gmail.com
}

Received: March 27, 2017

Accepted: April 17, $2017 \quad$ Online Published: April 24, 2017

doi:10.5539/ibr.v10n5p148

URL: https://doi.org/10.5539/ibr.v10n5p148

\begin{abstract}
This study tests whether free cash flow affects the performance of firms in the context of the free cash flow hypothesis. The study applies a panel regression method to a data set consisting of 2,175 observations belonging to 370 companies listed in Borsa Istanbul during the period 2009-2015. A significant, negative relationship is found between free cash flow and firm performance measured by Tobin's Q ratio. Greater free cash flow in the hands of managers leads to the lower performance and, conversely, less free cash flow in the hands of managers leads to higher performance. The results also confirm that leverage and di vidend payments have a positive effect on performance. Thus, the results support the free cash flow hypothesis for Turkey.
\end{abstract}

Keywords: free cash flow hypothesis, agency theory, free cash flow, Tobin's Q, Borsa Istanbul, emerging markets

\section{JEL Classification: G10, G15, G34, G35}

\section{Introduction}

As financial markets develop, the importance placed on corporate governance increases. Many countries, Turkey included, are taking steps the field of corporate governance by advancing its principles and putting regulations in place. The steps taken and regulations created are generally those of developed countries adapted to local conditions. Thus, a need arises for the both the theoretical framework and application to be tested in countries that adopt corporate governance structures. The results obtained contribute to the formulation of corporate governance regulations and/or principles more appropriate for the realities of the country.

The divergence of control and ownership of a firm, that is, the personal interests of managers and those of shareholders, leads to the agency problem (Jensen \& Meckling, 1976). After calling attention to the agency problem, Jensen $(1986,1993,1999)$ used agency theory as a launching point to propose the free cash flow hypothesis. According to this hypothesis, company managers prefer possess free cash flow that they can easily manipulate. They tend to use free cash flow for their own interests rather than those of shareholders. This leads, in particular, to investment in projects with negative net present value (Jensen, 1986; Jensen \& Meckling, 1976). Managers prioritize their own interests, making expenditures or poor decisions that result in losses known as agency cost that have a negative impact on company performance.

According to the free cash flow hypothesis, a negative correlation exists between company performance and the amount of free cash flow under the control of managers. Debt financing or dividend payouts reduce free cash flow, having a positive effect on company performance. Titman, Wei, and Xie (2003), Fairfield, Whisenant, and Yohn (2003) and Dechow, Richardson, and Sloan (2008) argued that company performance is negatively affected by overinvestment using free cash flow under managers' control. The work of Park and Jang (2013), Heydari, Milad, and Javadghayedi (2014), Brush, Bromiley, and Hendrickx (2000) and Wang (2010) also revealed a negative correlation between performance and free cash flow. Furthermore, Rozeff (1982) and Easterbrook (1984) found that dividend payouts or increases in dividend amounts were necessary for lowering agency costs. These findings have also been confirmed by DeAngelo and DeAngelo (2000) and La Porta, Lopez-de-Silanes, Shleifer, and Vishny (2000). Aigner, Lovell, and Schmidt (1977), on the other hand, reached different conclusions regarding dividends. 
Like many developed markets, corporate governance principles were first put in place in Turkey in order to reduce costs arising from the agency problem. In 2003 the "comply or explain" concept was first applied to Turkish corporate governance principles. In 2012 mandatory rules were put in place and in 2013 the Capital Market Law went into effect. This law elevates practices regarding corporate governance to the status of law. The new Turkish Commercial Code put into effect in 2012 bears influence of corporate governance principles (Alp \& Kılıç, 2014).

Legal infrastructure has been put in place in Turkey, and corporate governance principles are of the utmost importance. Now it is necessary to empirically test the theoretical appropriateness of the regulations and practices. The first phase of the free cash flow hypothesis, stating that dividend payouts, and the argument that external debt financing reduces free cash flow, was tested by Kadioglu and Yilmaz (2017) and the findings supported the free cash flow hypothesis. The second phase of testing the free cash flow hypothesis recommended by the researchers is the effect of free cash flow on company performance, which is the topic of this study.

Though many studies test corporate governance and company performance, dividend policy and corporate governance or capital structure and company performance in Turkey, there is no study directly testing free cash flow in the hands of managers and company performance in the context of the free cash flow hypothesis. This study aims to contribute to the literature by filling this gap. Furthermore, the conclusions reached in this study are likely to contribute to the formulation of regulations and principles in the field.

This study examines firms traded on Borsa Istanbul the validity of the free cash flow hypothesis, especially the relationship between free cash flow and company performance. This study utilizes the IFRS yearly nonconsolidated and consolidated financial statements of 370 firms traded on Borsa Istanbul for the period 2009-2015. A panel regression is used to test for a correlation between dividends per share, debt ratios as well as the ratio of free cash flow to total assets and the company performance measure Tobin's Q ratio. A dummy variable is used to differentiate between consolidated and nonconsolidated financial statements. The sample from the study by Kadioglu and Yilmaz (2017) is expanded and varied. While only nonconsolidated financial statements were used in Kadioglu and Yilmaz (2017), this study adds consolidated financial statements and the number of firms included in the study has been raised from 227 to 370. In addition, more current data are used by adding 2015 data, while 2008 data from the period of the financial crises have been removed.

The two-way fixed effect panel regression analysis identifies a significant, negative relationship between the Tobin's Q ratio, which measures company performance and free cash flow. In addition, a significant, positive relationship is identified between the Tobin's Q ratio and debt ratio and dividends per share. The results support the free cash flow hypothesis and are both compatible and complimentary with those of Kadioglu and Yilmaz (2017). As suggested by the hypothesis, a negative correlation is found between company performance and free cash flow. The reduction of free cash flow in the control of managers is found to have a positive effect on company performance, while increase of free cash flow has a negative effect.

The following section consists of a literature review. Section 3 discusses data and methods, while Section 4 outlines the results. Section 5 discusses the conclusions and makes further recommendations.

\section{Literature Review}

The divergence of company control and ownership, that is, the misalignment of managers' personal interests and those of shareholders gives rise to the agency problem (Jensen \& Meckling, 1976). Using the agency problem as a point of departure, Jensen $(1986,1993,1999)$ proposed the free cash flow hypothesis.

According to the free cash flow hypothesis, managers prefer to be in control of free cash flow that they can manipulate easily. Rather than using these funds for the benefit of shareholders, they may use it for their personal gain. For example, when there is an excess of funds, they are able to invest in projects with net negative present value (Jensen, 1986; Jensen \& Meckling, 1976). It may lead to lavish expenditures unrelated to company operations. Managers may prioritize their personal interests, making expenditures and poor decisions that lead to losses, known as agency cost, which has a negative impact on company performance. According to La Porta et al. (2000), agency cost may be an issue even in capital markets with more stringent rules and sanctions. According to Opler, Pinkowitz, Stulz, and Williamson (1999), agency cost can be seen more blatantly in company takeovers or acquisitions.

Managers who don't wish to be deprived of free cash flow under their control prefer to avoid policies that reduce free cash flow. According to the free cash flow hypothesis, dividend payouts and debt financing may reduce free cash flow (Kadioglu \& Yilmaz, 2017). Dividend payouts distribute the free cash flow in managers' control to shareholders. One of the methods used by managers who are need for cash is capital increases, collecting funds 
from shareholders. In nearly all countries, however, raising funds through capital increases is subject to strict rules like preparing a prospectus, public disclosure, independent audit and approval from a regulatory authority. In order to sidestep this method, managers prefer to avoid paying out dividends in the first place. Therefore, dividend payouts reduce free cash flow in the hands of managers and help to reduce agency cost.

Loans taken from external sources give the lenders claim over the borrowing firm, and in extreme cases the lender may demand that the borrower file bankruptcy. Therefore, managers averse to the threat of bankruptcy or pressure from lenders may not look favorably on external debt financing. According to Park and Jang (2013), securing funds from external sources reigns in overinvestment and the payment of interest on loans reduces free cash flow in the hands of managers.

Therefore, the free cash flow hypothesis proposes that a negative correlation exists between company performance and free cash flow. Thus, reducing free cash flow in managers' control gets rid of the agency cost, improving company performance. The way to reduce free cash flow, therefore, is by making the dividend payouts and securing external debt financing.

Rozeff (1982) and Easterbrook (1984) proposed that paying or increasing di vidend amounts is necessary in order to reduce agency cost. DeAngelo and DeAngelo (2000) and La Porta et al. (2000) also reached similar conclusions, which were also confirmed by Aigner et al. (1977). The thesis that external financing or dividends reduce free cash flow available to managers has been empirically supported by Lang, Ofek, and Stulz (1996), Li and Cui (2003), Byrd (2010), Khan, Kaleem, and Nazir (2012), Fatma and Chichti (2011) and Zhang (2009) and by Kadioglu and Yilmaz (2017) in the Turkish context.

Titman et al. (2003), Fairfield et al. (2003) and Dechow et al. (2008) put forth that in the case of free cash flow in the control of managers or overinvestment with these funds, company performance is negatively affected. Studies conducted by Park and Jang (2013), Heydari et al. (2014), Brush et al. (2000) and Wang (2010) found a negative relationship between free cash flow and performance.

Though many studies may exist in Turkey testing corporate governance and company performance (Çarıkçı, Kalaycı, \& Gök, 2009; Dağli, Ayaydin, \& Eyüboğlu, 2010; Ersoy, Bayrakdaroğlu, \& Şamıloğlu, 2011; İlhan, Topaloğlu, \& Özyamanoğlu, 2013; Karakoç, Nezih, \& Erhan, 2016; Karamustafa, Varıc1, \& Er, 2009; Kula \& Baykut, 2013; Taşkırmaz \& Bal, 2016; Yavuzaslan \& Kalmis, 2016; Yücel, 2016) or dividend policy and corporate governance (Aydin \& Cavdar, 2015; Gürbüz, Aybars, \& Kutlu, 2010; Mazgit, 2013; Mitton, 2004) or capital structure and company performance (Acaravc1, Kandır, \& Zelka, 2015; Doğan, 2013; Önem \& Demir, 2015) or corporate governance and share performance (K1lıç, 2011) no study exists testing the relationship between free cash flow and company performance in the context of agency cost resulting especially from corporate governance and the agency problem.

Table 1. Basic Data

\begin{tabular}{|c|c|c|c|c|c|c|c|c|}
\hline \multirow[b]{2}{*}{ Year } & \multicolumn{4}{|c|}{$\begin{array}{c}\text { Information on all firms traded on Borsa } \\
\text { Istanbul (million TL) }\end{array}$} & \multicolumn{4}{|c|}{ Information on firms included in the study (million TL) } \\
\hline & $\underset{\text { number }}{\text { Firm }}$ & $\begin{array}{l}\text { Transaction } \\
\text { volume }\end{array}$ & $\begin{array}{c}\text { Total } \\
\text { nominal } \\
\text { capital }\end{array}$ & $\begin{array}{l}\text { Total market } \\
\text { value }\end{array}$ & $\begin{array}{c}\text { Firm } \\
\text { number }\end{array}$ & Total assets & $\begin{array}{c}\text { Total } \\
\text { nominal } \\
\text { capital }\end{array}$ & $\begin{array}{l}\text { Total market } \\
\text { value }\end{array}$ \\
\hline 2009 & 325 & 482,500 & 70,061 & 350,761 & 258 & 403,143 & 39,697 & 154,120 \\
\hline 2010 & 350 & 635,700 & 80,806 & 472,553 & 277 & 482,416 & 47,718 & 259,359 \\
\hline 2011 & 373 & 694,876 & 89,274 & 381,152 & 299 & 574,781 & 53,728 & 297,407 \\
\hline 2012 & 395 & 621,979 & 96,634 & 550,051 & 334 & 648,917 & 59,882 & 360,281 \\
\hline 2013 & 405 & 816,858 & 103,179 & 503,668 & 348 & 703,165 & 66,032 & 388,099 \\
\hline 2014 & 401 & 870,962 & 104,540 & 624,369 & 347 & 765,931 & 66,304 & 380,585 \\
\hline 2015 & 395 & $1,025,874$ & 104,657 & 554,880 & 318 & 872,730 & 65,149 & 416,506 \\
\hline
\end{tabular}

Source: www.spk.gov.tr

\section{Data and Methodology}

\subsection{Data}

This study utilizes the IFRS yearly nonconsolidated and consolidated financial statements for the years 2009-2015 of 370 firms traded on Borsa Istanbul. A total of 2,175 observations are present in the study. When compiling the sample, financial institutions subject to their own regulations such as banks, insurance and retirement firms, brokerage houses, and securities investment associations were excluded. Firms traded on the stock exchange are required to prepare and disclose IFRS financial statements. If there is no subsidiary or participation subject to consolidation the financial statements are nonconsolidated. A dummy variable is used to distinguish between consolidated and nonconsolidated financial statements. Of the 2,175 observations used, 


\section{1,273 are derived consolidated and 902 from nonconsolidated financial statements.}

Table 1 displays information relating to companies traded on Borsa Istanbul from 2009 to 2015. The table shows the total market value, assets and nominal capital amount of the firms used in the study for the period 2009-2015.

Table 1 indicates that over $80 \%$ of traded firms are included in the study. Throughout the period of analysis, the number of firms traded on Borsa Istanbul increased 1.2 times, while the trade volume increased 2.1 times. Of the market value of the population, $65 \%$ is included while $61 \%$ of nominal capital is included. In the sample the total assets of the companies form the period 2009-2015 rose 13.82\% on average annually, while nominal capital rose at an average rate of $13.63 \%$ annually during the first 4 years. In the final year this rate dropped by $-1.74 \%$.

The data ranges from a minimum 2 years, maximum 7 years and an average of approximately 6 years. In years in which no dividends were paid the dividends per share rate is marked " 0 ". When calculating the free cash flow (FCF) variables used in the regression the FCF obtained are divided by total assets in order to get comparable results between firms (Chung, Firth, \& Kim, 2005; Gul \& Tsui, 1997; Lehn \& Poulsen, 1989; Mansourlakoraj \& Sepasi, 2015; Rahman \& Saleh, 2008).

The variables are calculated using the items in the budget and income table below.

Table 2. Variables

\begin{tabular}{llll}
\hline \multicolumn{1}{c}{ Variable } & \multicolumn{1}{c}{ Type } & \multicolumn{1}{c}{ Formula } \\
\hline$L N T Q$ & $:$ & Dependent & Ln ((market value + total debt)/total assets)) \\
$D P S$ & $:$ & Independent & Cash dividends / number of shares in circulation \\
$L E V$ & $:$ & Independent & Total external funds / total assets \\
$B V$ & $:$ & Control independent & Shareholder equity/ Paid-in capital (Book Value) \\
SIZE & $:$ & Control independent & Ln (total assets) \\
$F C F$ & $:$ & Independent & (Operating profit + depreciation expenses - corporate income tax - \\
& & financing expenses - cash dividends paid)/ total assets \\
\hline
\end{tabular}

When finding the market value of the firms, the daily average price over the entire year is used rather than that of a single day at the end of the year. Thus, the negative impact of possible price abnormalities of a particular day is avoided.

Table 3 displays the descriptive statistics of variables used in analysis.

Table 3. Descriptive statistics

\begin{tabular}{lcccccc}
\hline & $\boldsymbol{L n T \boldsymbol { q }}$ & $\boldsymbol{D P S}$ & $\boldsymbol{F C F}$ & $\boldsymbol{S I Z E}$ & $\boldsymbol{L E V}$ & $\boldsymbol{B V}$ \\
\hline Mean & -0.447 & 0.270 & -0.019 & 19.331 & 0.512 & 6.540 \\
Median & -0.474 & 0.000 & -0.007 & 19.292 & 0.461 & 2.120 \\
Maximum & 3.759 & 40.636 & 0.482 & 26.305 & 14.572 & 1124.158 \\
Minimum & -3.900 & 0.000 & -2.416 & 13.864 & 0.001 & -17.872 \\
Std. Dev. & 0.913 & 1.688 & 0.133 & 1.914 & 0.677 & 39.589 \\
Skewness & 0.294 & 17.114 & -6.321 & 0.212 & 11.652 & 21.417 \\
Kurtosis & 4.088 & 354.820 & 88.629 & 3.140 & 190.482 & 514.084 \\
Observations & 2175 & 2175 & 2175 & 2175 & 2175 & 2175 \\
\hline
\end{tabular}

Table 3 summarizes descriptive statistics relating to the sample, including the average, median, maximum and standard deviation of the 2,175 observations taken from 370 companies over 7 years.

Table 4 displays the correlation matrix between the variables.

Table 4. Correlation between variables

\begin{tabular}{lcccccc}
\hline & $\boldsymbol{D P S}$ & $\boldsymbol{F C F}$ & $\boldsymbol{L E} \boldsymbol{B}$ & $\boldsymbol{B V}$ & $\boldsymbol{L N T Q}$ & $\boldsymbol{S I Z E}$ \\
\hline$D P S$ & 1.00 & 0.07 & -0.04 & 0.69 & 0.12 & 0.01 \\
$F C F$ & 0.07 & 1.00 & -0.49 & 0.09 & -0.15 & 0.24 \\
LEV & -0.04 & -0.49 & 1.00 & -0.06 & 0.29 & -0.14 \\
$B V$ & 0.69 & 0.09 & -0.06 & 1.00 & 0.05 & 0.00 \\
LNTQ & 0.12 & -0.15 & 0.29 & 0.05 & 1.00 & -0.07 \\
SIZE & 0.01 & 0.24 & -0.14 & 0.00 & -0.07 & 1.00 \\
\hline
\end{tabular}

Table 4 shows that the correlation coefficients between variables are at low levels. Only the coefficient of the correlation between dividends per share and book value is higher, but still acceptable level.

\subsection{Methodology}

This study investigates the effect of free cash flow in the hands of managers on company performance as proposed in the free cash flow hypothesis in Turkish capital markets. According to the free cash flow hypothesis, high amounts of external debt financing or high dividend payouts reduce funds under the control of managers, which reduces agency cost and helps to align the interest of the managers and shareholders. The reduction of 
funds available to managers positively affects company performance. Therefore, this study seeks to determine whether a negative, significant relationship exists between free cash flow and company performance. At the same time, the existence of a connection between performance and debt ratios or dividend payouts is also investigated.

The Tobin's Q ratio is a widely used measure of manager performance used by Smith and Watts (1992), McConnell and Servaes (1995), Rajan and Zingales (1995), Himmelberg, Hubbard, and Palia (1999), Brush et al. (2000), Demsetz and Villalonga (2001), Harvey, Lins, and Roper (2004), Heydari et al. (2014). This measure has been used in the Turkish context by Canbas, Dogukanli, Düzakin, and Iskenderoglu (2005), Koçyigit (2009), Karamustafa et al. (2009), Ersoy et al. (2011), Mandac1 and Gumus (2010), Şahin (2011), Doğan and Yildiz (2013), Acaravc1 et al. (2015), Önem and Demir (2015), Yücel (2016). Other studies have taken the logarithm of the Tobin's Q ratio and entered it into an analysis (Kazempour \& Aghaei, 2015; Mansourlakoraj \& Sepasi, 2015; Park \& Jang, 2013).

Lehn and Poulsen (1989), Lang, Stulz, and Walkling (1991), Wells, Cox, and Gaver (1995), Chu (2011), Gul and Tsui (1997), Wu (2004), Chung et al. (2005), Brush et al. (2000), Wang (2010), Al-Zararee and Al-Azzawi (2014), Mansourlakoraj and Sepasi (2015), Rahman and Saleh (2008) and Kadioglu and Yilmaz (2017) used the undistributed free cash flow method when calculating free cash flow.

The free cash flow hypothesis proposes that free cash flow in the hands of managers is inversely proportionate to company performance due to agency cost. According to the hypothesis, external debt financing and dividend payouts reduce amount of free cash flow in the hands of managers and increase market enforcement upon managers, which has a positive effect on company performance. Therefore, the effect of leverage and dividends on company performance is also investigated. For this purpose, data from 370 firms from the period 2009-2015 are applied to the equation and panel regression below. This equation has been used by Brush et al. (2000), Mansourlakoraj and Sepasi (2015), Heydari et al. (2014), Park and Jang (2013). A variation using similar performance measures other than Tobin's Q has been used by Hong, Shuting, and Meng (2012), Nunez; Nunez (2013, 2014), Al-Zararee and Al-Azzawi (2014).

$$
L n T q_{i, t}=\alpha+\beta_{1} D P S_{i, t}+\beta_{2} L E V_{i, t}+\beta_{3} B V_{i, t}+\beta_{4} S I Z E_{i, t}+\beta_{5} F C F_{i, t}+\beta_{6} \text { Kons }_{i, t}+\varepsilon_{i, t}
$$

Here, $L n T q_{i, t}$ expresses the logarithm of the Tobin's Q ratio of firm $i$ in year $t$, while $D P S_{i, t}$ is the ratio of cash dividends per share for firm $i$ in year $t$. The variable $L E V_{i, t}$ represents the ratio of total debt to total assets for firm $i$ in year $t$, while $B V_{i, t}$ expresses the book value of firm $i$ in year $t$. The variable $S I Z E_{i, t}$ represents the logarithm of total assets of firm $i$ in year $t$, while Kons $s_{i, t}$ is the dummy variable indicating whether the observation of firm $i$ in year $t$ belongs to a consolidated or unconsolidated financial statements. The variable $F C F_{i, t}$ is the ratio of free cash flow to total assets.

This study relies on the following hypotheses when testing the free cash flow hypothesis especially when concerning the relationship between free cash flow and company performance.

H1: Free cash flow under managers' control negatively affects company performance.

H1 a: Dividend payouts positively affect company performance.

H1b: External debt financing positively affect company performance.

\section{Results}

Empirical studies analyze data with the assumption that they possess a constant mean over time. Panel data, however, are sometimes non-constant, as it unknown whether they possess a unit root. According to some researchers, the non-stationary nature of the data or the presence of a unit root causes the variable to have a non-constant mean over time. This also leads to a high autocorrelation problem despite a low Durbin-Watson statistic (Kutty, 2010).

All of the variables in this study are subject to a unit root tests as have been performed by Levin, Lin, and Chu (2002), Im, Pesaran, and Shin (2003) and Augmented Dickey and Fuller (1979). According to the unit root test results, apart from the SIZE variable, all are free of unit roots. As for the SIZE variable, by taking the difference on the first level it was made stationary. Table 5 displays the final test results. 
Table 5. Unit root tests

\begin{tabular}{|c|c|c|c|c|}
\hline & & Levin, Lin and Chu & Im, Pesaran and Shin W-s tat & ADF - Fisher chi-square \\
\hline \multirow{2}{*}{$L n T q$} & Stat & -83.47 & -17.32 & 1108 \\
\hline & Prob. & 0.00 & 0.00 & 0.00 \\
\hline \multirow{2}{*}{$F C F$} & Stat & -70.71 & -21.48 & 1721 \\
\hline & Prob. & 0.00 & 0.00 & 0.00 \\
\hline \multirow{2}{*}{$D P S$} & Stat & -25653 & -1418 & 516.60 \\
\hline & Prob. & 0.00 & 0.00 & 0.00 \\
\hline \multirow{2}{*}{$D(S I Z E)$} & Stat & -85.35 & -20.66 & 1591 \\
\hline & Prob. & 0.00 & 0.00 & 0.00 \\
\hline \multirow{2}{*}{$L E V$} & Stat & -31.37 & -6.18 & 1072 \\
\hline & Prob. & 0.00 & 0.00 & 0.00 \\
\hline \multirow{2}{*}{$B V$} & Stat & -161.71 & -14.78 & 1032 \\
\hline & Prob. & 0.00 & 0.00 & 0.00 \\
\hline
\end{tabular}

Note. The probability value less than $5 \%$ indicates a rejection of the null hypothesis that a unit root is present. As seen in Table 5, the variables used in this study are stationary or have been transformed to stationary, as the probability rate of three different test results have a statistical significance of $1 \%$.

This study aims to test the free cash flow hypothesis proposed by Jensen $(1986,1993,1999)$. The hypothesis states that, dividend payments to shareholders and/or raising debt financing reduces the agency cost resulting from free cash flow in the hands of managers, therefore, improving firm performance. Thus, it is proposed that a negative correlation exists between free cash flow and performance. Another argument of the hypothesis is that debt financing and dividend payouts affecting free cash flow also affect performance indirectly.

Table 6 displays the results of the equations used to test the relationships mentioned above. Given that the effects of the 2008 global financial crisis might carry over into 2009, the results were repeated both including and excluding the year 2009. The regression repeated without 2009 both controlled for the effects of the crisis and also showed whether the crisis had any effect at all.

Table 6. Two-way, fixed-effect panel regression results

\begin{tabular}{|c|c|c|c|c|}
\hline \multirow[b]{2}{*}{ Variable } & \multicolumn{2}{|c|}{ Entire period (2009-2015) } & \multicolumn{2}{|c|}{ Post-crisis period (2010-2015) } \\
\hline & Coefficient & T-statistics & Coefficient & T-statistics \\
\hline Constant & 0.130709 & $5.90^{*}$ & 0.154519 & $6.27^{*}$ \\
\hline$D P S$ & 0.057138 & $4.46^{*}$ & 0.045680 & $3.19^{*}$ \\
\hline$F C F$ & -0.264276 & $-3.43^{*}$ & -0.310998 & $-3.83^{*}$ \\
\hline$L E V$ & 0.153445 & $7.15^{*}$ & 0.164166 & $6.40^{*}$ \\
\hline$D(S I Z E)$ & -0.065330 & $-2.95^{*}$ & -0.059394 & $-2.67^{*}$ \\
\hline$B V$ & -0.004118 & $-6.92^{*}$ & -0.004413 & $-5.38^{*}$ \\
\hline Kons & 0.026451 & 0.83 & 0.028006 & 0.79 \\
\hline F-statistics & \multicolumn{2}{|c|}{$14.96^{*}$} & \multicolumn{2}{|c|}{$14.57^{*}$} \\
\hline Adj $R^{2}$ & \multicolumn{2}{|c|}{0.70} & \multicolumn{2}{|c|}{0.73} \\
\hline
\end{tabular}

Note. ${ }^{*}$ indicates a statistical significance of $1 \%$. Due to insufficient observation resulting from unbalanced data, the Hausman test is performed as a one-way, random-effects model. The Hausman test is recommended the fixed-effect model.

According to the model outlined in Table 6,70\% percent of variability in the Tobin's Q ratio can be explained with variability in the of free cash flow, debt ratio, total asset and book value variables. The estimated model's general statistical significance level shown by the $F$-statistic is at a $1 \%$ level. To see the effects following the 2008 global crisis, it is seen that the results in the regression did not change.

Again in Table 6 it is seen that the free cash flow-asset ratio has a negative correlation with the Tobin's Q ratio with $1 \%$ significance. While the higher free cash flow in the control of managers has a positive effect on company performance, the lower free cash flow negatively affects performance. Inverse relationship between free cash flow under the control of managers and performance demonstrates that the fundamental argument of the free cash flow hypothesis is valid in the Turkish context. These results are compatible with the findings of Titman et al. (2003), Fairfield et al. (2003), Dechow et al. (2008), Park and Jang (2013), Heydari et al. (2014), Brush et al. (2000) and Wang (2010). The hypothesis argues that using external debt financing and dividend payout reduces the amount of free cash flow in the hands of managers. This aspect of the hypothesis was tested in the Turkish context by Kadioglu and Yilmaz (2017), who reached conclusions supporting the hypothesis.

According to the free cash flow hypothesis developed by Jensen (1986), paying out dividends is one method of reducing agency cost resulting from a conflict of managers' and shareholders' interests. Looking at the effects of 
debt ratios and dividend payouts on company performance, a positive relationship with a statistical significance of $1 \%$ is identified between the debt ratio $L E V$ and the Tobin's Q ratio $L n T q$ as well as between dividend payout rate DPS and $L n T q$. External debt funding was similarly found to boost company performance in the studies of Fama and French (2002), Gill, Biger, and Mathur (2011), Ramachandran and Candasamy (2011), Kazempour and Aghaei (2015), Park and Jang (2013), Acaravc1 et al. (2015) and Doğan (2013). For firms traded on Borsa Istanbul, using external debt financing and dividend payouts reduces free cash flow in the hands of managers, therefore, enhancing company performance. When considered along with those of Kadioglu and Yilmaz (2017), these results show that the free cash flow hypothesis is valid in the Turkish context.

\section{Conclusion}

When the interests of company managers and those of shareholders are in conflict, agency cost arises due to the agency problem. This can lead to the use of free cash flow for investments with a negative net present value or lavish expenditures not directly related to company operations, therefore having a negative impact on company performance. According to the free cash flow hypothesis, free cash flow can be reduced with dividend payouts and securing external debt financing. This way firms can strengthen their performance.

This study investigates the validity of the free cash flow hypothesis. More precisely, it tests for a negative correlation between free cash flow and company performance for firms traded on Borsa Istanbul. The study utilizes the IFRS yearly consolidated and nonconsolidated financial statements of 370 firms for the period 2009-2015. A two-way panel regression method is applied to dividends per share, debt ratios and free cash flow-to-asset ratio and the performance measure Tobin's $\mathrm{Q}$ ratio to test for any correlation.

The results of the two-way fixed-effect panel regression reveal a negative, statistically significant relationship between the Tobin's Q ratio and free cash flow. Furthermore, a significant relationship is also identified between the Tobin's Q ratio and debt ratio and dividends per share. The results support the free cash flow hypothesis, and are both compatible and complimentary to those of Kadioglu and Yilmaz (2017). As suggested by the hypothesis, free cash flow in the hands of managers has a negative correlation with company performance. The reduction of free cash flow under managers' control is shown to have a positive effect on company performance, while increases in free cash flow are shown to have a negative effect.

Given that increased importance is being placed on corporate governance in Turkey, this study's test of the theoretical framework can contribute to the formation of regulations and principles in this area. According to the free cash flow hypothesis, free cash flow leads to agency cost and negatively affects firm performance; therefore it may be beneficial to adopt these principles and/or create regulations that discipline or reduce free cash flow in the hands of managers. In order to reduce free cash flow, dividend payout should be regulated through corporate governance principles, which can be used as a political tool by regulatory authorities.

\section{References}

Acaravcı, S. K., Kandır, S. Y., \& Zelka, A. (2015). Kurumsal Yönetimin BIST Şirketlerinin Performanslarına Etkisinin Araştırılması. Ömer Halisdemir Üniversitesi İktisadi ve İdari Bilimler Fakültesi Dergisi, 8(1), 171-183.

Aigner, D., Lovell, C. K., \& Schmidt, P. (1977). Formulation and estimation of stochastic frontier production function models. Journal of Econometrics, 6(1), 21-37. https://doi.org/10.1016/0304-4076(77)90052-5

Alp, A., \& Kılıç, S. (2014). Kurumsal yönetim nasıl yönetilmeli. Doğan Kitap, İstanbul.

Al-Zararee, A., \& Al-Azzawi, A. (2014). The Impact of Free Cash Flow on Market Value of Firm. Global Review of Accounting and Finance, 5(2), 56-63. https://doi.org/10.21102/graf.2014.09.52.04

Aydin, A. D., \& Cavdar, S. C. (2015). Corporate governance and dividend policy: An empirical analysis from borsa Istanbul corporate governance index (xkury). Accounting and Finance Research, 4(3), 66-76. https://doi.org/10.5430/afr.v4n3P66

Brush, T. H., Bromiley, P., \& Hendrickx, M. (2000). The free cash flow hypothesis for sales growth and firm performance. Strategic Management Journal, 21(4), 455-472. https://doi.org/10.1002/(SICI)1097-0266(200004)21:4<455::AID-SMJ83>3.0.CO;2-P

Byrd, J. W. (2010). Financial policies and the agency costs of free cash flow: Evidence from the oil industry. International Review of Accounting, Banking and Finace, 2(2), 22-49. https://doi.org/10.2139/ssrn.1664654

Canbas, S., Dogukanli, H., Düzakin, H., \& Iskenderoglu, Ö. (2005). Performans Ölçümünde Tobin Q Oraninin Kullanilmasi: Hisse Senetleri IMKB"de Islem Gören Sanayi Isletmeleri Üzerinde Bir Deneme. Journal of Accounting \& Finance, 28, 24-36. 
Chu, J. (2011). Agency Cost under the Restriction of Free Cash Flow. Journal of Service Science and Management, 04(01), 79-85. https://doi.org/10.4236/jssm.2011.41011

Chung, R., Firth, M., \& Kim, J. B. (2005). Earnings management, surplus free cash flow, and external monitoring. Journal of business research, 58(6), 766-776. https://doi.org/10.1016/j.jbusres.2003.12.002

Çarıkçı, H. İ., Kalaycı, S., \& Gök, İ. Y. (2009). Kurumsal Yönetim-Şirket Performansı İlişkisi: İMKB Kurumsal Yönetim Endeksi Üzerine Amprik Bir Çalışma. Alanya İşletme Fakültesi Dergisi, 1, 52-71.

Dağli, H., Ayaydin, H., \& Eyüboğlu, K. (2010). Kurumsal Yönetim Endeksi Performans Değerlendirmesi:Türkiye Örneği. Journal of Accounting \& Finance, 48, 18-31.

DeAngelo, H., \& DeAngelo, L. (2000). Controlling stockholders and the disciplinary role of corporate payout policy: A study of the Times Mirror Company. Journal of Financial Economics, 56(2), 153-207. https://doi.org/10.1016/S0304-405X(00)00039-8

Dechow, P. M., Richardson, S. A., \& Sloan, R. G. (2008). The Persistence and Pricing of the Cash Component of Earnings. Journal of Accounting Research, 46(3), 537-566. https://doi.org/10.1111/j.1475-679X.2008.00283.x

Demsetz, H., \& Villalonga, B. (2001). Ownership structure and corporate performance. Journal of Corporate Finance, 7(3), 209-233. https://doi.org/10.1016/S0929-1199(01)00020-7

Dickey, D. A., \& Fuller, W. A. (1979). Distribution of the Estimators for Autoregressive Time Series With a Unit Root. Journal of the American Statistical Association, 74(366), 427. https://doi.org/10.2307/2286348

Doğan, M. (2013). Sigorta Firmalarının Sermaye Yapısı İle Karlılık Arasındaki İişki: Türk Sermaye Piyasası Üzerine Bir İnceleme. Journal of Accounting \& Finance, 57, 121-136.

Doğan, M., \& Yildiz, F. (2013). The Impact of the Board of Directors' Size on the Bank's Performance: Evidence from Turkey. European Journal of Business and Management, 5(6), 130-140.

Easterbrook, F. H. (1984). Two agency-cost explanations of dividends. American Economic Review. (74), 650-659.

Ersoy, E., Bayrakdaroğlu, A., \& Şamıloğlu, F. (2011). Türkiye'de kurumsal yönetim ve firma performansı (Tobin-Q ve anormal getiri) ve firma performans1. Finans Politik \& Ekonomik Yorumlar, 48(554), 71-83.

Fairfield, P. M., Whisenant, J. S., \& Yohn, T. L. (2003). Accrued Earnings and Growth: Implications for Future Profitability and Market Mispricing. The Accounting Review, 78(1), 353-371. https://doi.org/10.2308/accr.2003.78.1.353

Fama, E. F., \& French, K. R. (2002). Testing Trade-Off and Pecking Order Predictions About Dividends and Debt. Review of Financial Studies, 15(1), 1-33. https://doi.org/10.1093/rfs/15.1.1

Fatma, B. M., \& Chichti, J. (2011). Interactions between free cash flow, debt policy and structure of governance:Three stage least square simultaneous model approach. Journal of Management Research, 3 , $1-34$.

Gill, A., Biger, N., \& Mathur, N. (2011). The effect of capital structure on profitability: Evidence from the United States. International Journal of Management, 28(4), 3-14.

Gul, F. A., \& Tsui, J. S. L. (1997). A test of the free cash flow and debt monitoring hypotheses: Evidence from audit pricing. Journal of Accounting and Economics, 24(2), 219-237. https://doi.org/10.1016/S0165-4101(98)00006-8

Gürbüz, A. O., Aybars, A., \& Kutlu, Ö. (2010). Corporate governance and financial performance with a perspective on institutional ownership: Empirical evidence from Turkey. Journal of Applied Management Accounting Research, 8(2), 21-37.

Harvey, C. R., Lins, K. V., \& Roper, A. H. (2004). The effect of capital structure when expected agency costs are extreme. Journal of Financial Economics, 74(1), 3-30. https://doi.org/10.1016/j.jfineco.2003.07.003

Heydari, I., Milad, M., \& Javadghayedi, M. (2014). Investigating the relationshipbetween free cash flowsandfirm performance: evidencefrom tehran stock exchange. Indian J. Sci. Res, 4, 269-279.

Himmelberg, C. P., Hubbard, R., \& Palia, D. (1999). Understanding the determinants of managerial ownership and the link between ownership and performance. Journal of Financial Economics, 53(3), 353-384. https://doi.org/10.1016/S0304-405X(99)00025-2 
Hong, Z., Shuting, Y., \& Meng, Z. (2012). Relationship between free cash flow and financial performance evidence from the listed real estate companies in China. IPCSIT, 36, 331-335.

Im, K. S., Pesaran, M., \& Shin, Y. (2003). Testing for unit roots in heterogeneous panels. Journal of Econometrics, 115(1), 53-74. https://doi.org/10.1016/S0304-4076(03)00092-7

İlhan, E., Topaloğlu, E. E., \& Özyamanoğlu, M. (2013). Finansal Performans İle Kurumsal Yönetim Notlari Arasindaki İlişki: Bist üzerine bir uygulama. Akademik Araştırmalar ve Çalışmalar Dergisi, 9, 100-117.

Jensen, M. C. (1986). Agency costs of free cash flow, corporate finance and takeovers. American Economic Review, 76(2), 323-329.

Jensen, M. C. (1993). The Modern Industrial Revolution, Exit, and the Failure of Internal Control Systems. The Journal of Finance, 48(3), 831-800. https://doi.org/10.1111/j.1540-6261.1993.tb04022.x

Jensen, M. C. (1999). Eclipse of the Public Corporation. SSRN Electronic Journal. Advance online publication. https://doi.org/10.2139/ssrn.146149

Jensen, M. C., \& Meckling, W. H. (1976). Theory of the firm: Managerial behavior, agency costs and ownership structure. Journal of Financial Economics, 3(4), 305-360. https://doi.org/10.1016/0304-405X(76)90026-X

Kadioglu, E., \& Yilmaz, E. A. (2017). Is the free cash flow hypothesis valid in Turkey? Borsa Istanbul Review. Advance online publication. https://doi.org/10.1016/j.bir.2016.12.001

Karakoç, M., Nezih, T., \& Erhan, G. (2016). Gri İlişkisel Analiz Yöntemiyle Kurumsal Yönetim Endeksinde Yer Alan Şirketlerin Finansal Performanslarinin Ölçümü Ve Kurumsal Derecelendİrme Notlari İlişkisi. Elektronik Sosyal Bilimler Dergisi, 15, 1327-1338. https://doi.org/10.17755/esosder.39921

Karamustafa, O., Varıcı, İ., \& Er, B. (2009). Kurumsal yönetim ve firma performansı: İMKB kurumsal yönetim endeksi kapsamındaki firmalar üzerinde bir uygulama. Kocaeli Üniversitesi Sosyal Bilimler Enstitüsü Dergisi, 17(1), 100-119.

Kazempour, M., \& Aghaei, M. A. (2015). Capital Structure and Firms Performance in Tehran Stock Exchange. International Joural of Managemnt, Acoutning and Economics, 2(2), 149-152.

Khan, A., Kaleem, A., \& Nazir, M. S. (2012). Impact of financial leverage on agency cost of free cash flow: Evidence from the manufacturing sector of Pakistan. Journal of Basic and Applied Scientific Research, 2(7), 6694-6700.

Kılıç, S. (2011). İMKB Kurumsal Yönetim Endeksine Dâhil Olan Şirketlerin Getiri Performanslarinin Ölçülmesi. Finans Politik ve Ekonomik Yorumlar Dergisi, 48(552), 45-58.

Koçyigit, M. (2009). Havayolu Isletmelerinin Performansinin Tobin q Orani ile Ölçülmesi. Journal of Accounting \& Finance. (44), 179-189.

Kula, V., \& Baykut, E. (2013). Kurumsal Yönetim Endeksinde Yer Almanın Mevduat Bankalarının Performansına Etkisi: BíST Örneği. Afyon Kocatepe Üniversitesi Sosyal Bilimler Dergisi, 15(2), 121-136. https://doi.org/10.5578/JSS.7204

Kutty, G. (2010). Venture capital funds: The Relationship Between Exchange Rates and Stock Prices: The Case of Mexico. Journal of Banking \& Finance, 4, 1-13. https://doi.org/10.1016/j.jbankfin.2009.08.022

La Porta, R., Lopez-de-Silanes, F., Shleifer, A., \& Vishny, R. W. (2000). Agency Problems and Dividend Policies around the World. The Journal of Finance, 55(1), 1-33. https://doi.org/10.1111/0022-1082.00199

Lang, L., Ofek, E., \& Stulz, R. (1996). Leverage, investment, and firm growth. Journal of Financial Economics, 40(1), 3-29. https://doi.org/10.1016/0304-405X(95)00842-3

Lang, L. H., Stulz, R., \& Walkling, R. A. (1991). A test of the free cash flow hypothesis. Journal of Financial Economics, 29(2), 315-335. https://doi.org/10.1016/0304-405X(91)90005-5

Lehn, K., \& Poulsen, A. (1989). Free Cash Flow and Stockholder Gains in Going Private Transactions. The Journal of Finance, 44(3), 771. https://doi.org/10.1111/j.1540-6261.1989.tb04390.x

Levin, A., Lin, C.-F., \& Chu, C.-S. J. (2002). Unit root tests in panel data: Asymptotic and finite-sample properties. Journal of Econometrics, 108(1), 1-24. https://doi.org/10.1016/S0304-4076(01)00098-7

Li, H., \& Cui, L. (2003). Empirical study of capital structure on agency costs in Chinese listed firms. Nature and science, $1(1), 12-20$. 
Mandac1, P., \& Gumus, G. (2010). Ownership Concentration, Managerial Ownership and Firm Performance: Evidence from Turkey. South East European Journal of Economics and Business, 5(1), 57-66. https://doi.org/10.2478/v10033-010-0005-4

Mansourlakoraj, R., \& Sepasi, S. (2015). Free Cash Flow, Capital Structure and the Value of Listed Companies in Tehran Stock Exchange. International Journal of Management, Accounting and Economics, 2(2), 144-148.

Mazgit, I. (2013). Endeks Kapsaminda Olmanin Hisse Senedi Getirilerine Etkisi BIST Temettü 25 Endeksi Üzerine Bir Uygulama. Sosyoekonomi, 2, 225-264.

McConnell, J. J., \& Servaes, H. (1995). Equity ownership and the two faces of debt. Journal of Financial Economics, 39(1), 131-157. https://doi.org/10.1016/0304-405X(95)00824-X

Mitton, T. (2004). Corporate governance and dividend policy in emerging markets. Emerging Markets Review, 5(4), 409-426. https://doi.org/10.1016/j.ememar.2004.05.003

Nunez, K. (2013). Free Cash Flow and Performance Predictability in Electric Utilities. Journal of Business and Policy Research, 8(1), 19-38.

Nunez, K. (2014). Free cash flow and performance predictability: An industry analysis. International Journal of Business, Accounting, \& Finance, 8(2), 120-135.

Opler, T., Pinkowitz, L., Stulz, R., \& Williamson, R. (1999). The determinants and implications of corporate cash holdings. Journal of Financial Economics, 52(1), 3-46. https://doi.org/10.1016/S0304-405X(99)00003-3

Önem, H. B., \& Demir, Y. (2015). Mülkiyet Yapisinin Firma Performansina Etkisi: BIST Imalat Sektörü Üzerine Bir Uygulama. Süleyman Demirel Üniversitesi Vizyoner Dergisi, 6(13), 31-43.

Park, K., \& Jang, S. (2013). Effects of within-industry diversification and related diversification strategies on firm performance. International Journal of Hospitality Management, 33, 51-60. https://doi.org/10.1016/j.ijhm.2013.02.009

Rahman, A. F., \& Saleh, N. M. (2008). The effect of free cash flow agency problem on the value relevance of earnings and book value. Journal of Financial Reporting and Accounting, 6, 75-90. https://doi.org/10.1108/19852510880000636

Rajan, R. G., \& Zingales, L. (1995). What Do We Know about Capital Structure? Some Evidence from International Data. The Journal of Finance, 50(5), 1421-1460. https://doi.org/10.1111/j.1540-6261.1995.tb05184.x

Ramachandran, A., \& Candasamy, G. (2011). The impact of capital structure on profitability with special reference to IT industry in India vs. domestic products. Managing Global Transitions, 9(4), 371-392.

Rozeff, M. S. (1982). Growth, Beta, and Agency Costs as Determinants of Dividend Payout Ratios. Journal of Financial Research, 5(3), 249-259. https://doi.org/10.1111/j.1475-6803.1982.tb00299.x

Smith, C. W., \& Watts, R. L. (1992). The investment opportunity set and corporate financing, dividend, and compensation policies. Journal of Financial Economics, 32(3), 263-292. https://doi.org/10.1016/0304-405X(92)90029-W

Şahin, O. (2011). İMKB’ye Kayıtlı İmalat Şirketlerinde Çalışma Sermayesi Politikaları ve Firma Performansı İlişkileri. Eskişehir Osmangazi Üniversitesi İ̈BF Dergisi, 6(2), 123-141.

Taşkırmaz, M., \& Bal, C. G. (2016). Relationship between corporate governance and corporate sustainability: A sample of borsa Istanbul, Turkey, 2(2), 74-186. https://doi.org/10.18844/ijire.v2i2.354

Titman, S., Wei, K. C. J., \& Xie, F. (2003). Capital investments and stock returns. NBER working paper series: Vol. 9951. Cambridge, Mass.: National Bureau of Economic Research. https://doi.org/10.3386/w9951

Wang, G. Y. (2010). The Impacts of Free Cash Flows and Agency Costs on Firm Performance. Journal of Service Science and Management, 03(04), 408-418. https://doi.org/10.4236/jssm.2010.34047

Wells, B. P., Cox, L. A., \& Gaver, K. M. (1995). Free Cash Flow in the Life Insurance Industry. The Journal of Risk and Insurance, 62(1), 50-66. https://doi.org/10.2307/253692

$\mathrm{Wu}, \mathrm{L}$. (2004). The impact of ownership structure on debt financing of Japanese firms with the agency cost of free cash flow. SSRN Electronic Journal. https://doi.org/10.2139/ssrn.488042 
Yavuzaslan, S., \& Kalmis, H. (2016). Isletmelerin Kurumsal Yönetim Uygulamalarinin Kâr Yönetimi Üzerindeki Etkisi ve Borsa Istanbul AS Sirketleri Üzerinde Bir Uygulama. Çanakkale Onsekiz Mart Üniversitesi Yönetim Bilimleri Dergisi, 14(27), 353-384.

Yücel, E. (2016). Kurumsal yönetim ve firma performansi: Gelişmiş ve gelişmekte olan ülkelerden kanitlar. Organizasyon ve Yönetim Bilimleri Dergisi, 8(2), 27-41.

Zhang, Y. (2009). Are Debt and Incentive Compensation Substitutes in Controlling the Free Cash Flow Agency Problem? Financial Management, 38(3), 507-541. https://doi.org/10.1111/j.1755-053X.2009.01046.x

\section{Copyrights}

Copyright for this article is retained by the author(s), with first publication rights granted to the journal.

This is an open-access article distributed under the terms and conditions of the Creative Commons Attribution license (http://creativecommons.org/licenses/by/4.0/). 